\title{
A new species of Mirocaris (Crustacea: Decapoda: Caridea: Alvinocarididae) associated with hydrothermal vents on the Central Indian Ridge, Indian Ocean*
}

\author{
TOMOYUKI KOMAI ${ }^{1}$, JOEL W. MARTIN ${ }^{2}$, KRISTA ZALA $^{2}$, SHINJI TSUCHIDA $^{3}$ \\ and JUN HASHIMOTO ${ }^{4}$ \\ ${ }^{1}$ Natural History Museum and Institute, Chiba, 955-2 Aoba-cho, Chuo-ku, Chiba 260-8682, Japan. \\ E-mail: komai@chiba-muse.or.jp \\ ${ }^{2}$ Natural History Museum of Los Angeles County, 900 Exposition Boulevard, Los Angeles, California 90007, U.S.A. \\ ${ }^{3}$ Japan Agency for Marine-Earth Science Technology (JAMSTEC), 2-15 Natsushima-cho Yokosuka, 237-0061, Japan. \\ ${ }^{4}$ Faculty of Fisheries, Nagasaki University, 1-14 Bunkyo, Nagasaki 852-8521, Japan.
}

\begin{abstract}
SUMMARY: Mirocaris indica, a new species of the caridean family Alvinocarididae, is described based on 17 specimens from hydrothermal vent fields on the Central Indian Ridge near the Rodriguez Triple Junction. The new species closely resembles the only known representative of Mirocaris, the Atlantic species M. fortunata (Martin and Christiansen). Shared major characters include the dorsoventrally flattened, unarmed rostrum, the presence of epipods on the third maxilliped through to the fourth pereopod with corresponding setobranchs on the first to fifth pereopods, and the lack of appendices internae on the third and fourth pleopods. However, the lack of submarginal rows of short to long stiff setae on the external surfaces of the fingers of the first chela distinguishes $M$. indica from $M$. fortunata, and may reflect a difference in feeding habit between the two species. Further, $M$. indica may attain a larger adult size than $M$. fortunata does.
\end{abstract}

Key words: Crustacea, Decapoda, Caridea, Alvinocarididae, Mirocaris, new species, Central Indian Ridge, hydrothermal vent.

RESUMEN: Una nueva especie de Mirocaris (Crustacea: Decapoda: Caridea: Alvinocarididae) asociada con fuenTES hidRotermales en la DORSAl CENTRAl ÍNDICA, OCÉANo Í́NDICO. - Mirocaris indica, una nueva especie de la família caridea Alvinocarididae, se describe basándose en 17 especímenes obtenidos en campos de fuentes hidrotermales de la Dorsal Central Índica cerca de la Triple Convergencia de Rodríguez. La nueva especie es muy parecida al único representante de Mirocaris, la especie atlántica M. fortunata (Martin y Christiansen). Los principales caracteres compartidos incluyen el rostro inerme, aplanado dorsoventralmente, la presencia de epipodios en el tercer maxilípedo hasta el cuarto pereiópodo con correspondientes setobránquias en los pereiópodos primero a quinto, así como la falta de appendices internae en los pleópodos tercero y cuarto. La falta de filas submarginales de cortas a largas sedas rígidas sobre las superfícies externas de los dedos de la primera quela distinguen, no obstante, $M$. indica de $M$. fortunata, y pueden reflejar una diferencia en hábitos alimenticios entre las dos especies. Adicionalmente, $M$. indica alcanza una talla adulta superior a la de M. fortunata.

Palabras clave: Crustacea, Decapoda, Caridea, Alvinocarididae, Mirocaris, especie nueva, Dorsal Central Índica, fuentes hidrotermales.

\section{INTRODUCTION}

Recent studies have rapidly increased our knowledge of the taxonomy of decapod crustaceans

*Received December 12, 2004. Accepted July 22, 2005. endemic to hydrothermal vents and cold seeps (e.g. Baba and Williams, 1998; Kikuchi and Hashimoto, 2000; Takeda et al., 2000; Hayashi and Ohtomi, 2001; Guinot et al., 2002; Tsuchida and Hashimoto, 2002; Watabe and Hashimoto, 2002; Guinot and Hurtado, 2003; Shank and Martin, 2003; Webber, 
2004; Komai and Segonzac, 2003, 2004, 2005a, 2005b; Martin and Shank, 2005; Komai et al., in press; reviewed by Martin and Haney, in press). However, a number of newly discovered species, particularly in the caridean family Alvinocarididae, remain undescribed (Shank et al., 1999; Webber, 2004; Komai and Segonzac, 2005; Martin and Haney, in press). In this paper, we describe a new species of the genus Mirocaris Vereshchaka, 1997, based on 17 specimens from hydrothermal vent fields on the Central Indian Ridge, where another alvinocaridid, Rimicaris kairei Watabe and Hashimoto, 2002, has been described.

Mirocaris was originally established for two taxa from the Mid-Atlantic Ridge by Vereshchaka (1997): M. keldyshi Vereshchaka, 1997 (designated as the type species of the genus), and Chorocaris fortunata Martin and Christiansen, 1995. In their recent review of the genus Mirocaris, Komai and Segonzac (2003) reduced M. keldyshi to a synonym of $M$. fortunata and redefined the genus. Thus, prior to this study there was only one known species of Mirocaris: the Atlantic M. fortunata (Martin and Christiansen, 1995).

Mirocaris is characterized by the dorsoventrally flattened, non-dentate rostrum and the possession of epipods on the third maxilliped through to the fourth pereopod, with a corresponding setobranch on the first to fifth pereopods. The new species is assigned to Mirocaris based on these features. Although it closely resembles $M$. fortunata, we confer full specific status for the Indian Ocean population because of the presence of a constant morphological difference in the setation of the chela of the first pereopod.

\section{MATERIAL AND METHODS}

Holotype and other paratypic specimens in the collection of JAMSTEC were collected during the YK01-15 cruise from 2nd to 24th February 2002. Ten dives of the submersible Shinkai 6500 were conducted at the Kairei Field $\left(25^{\circ} 19.2^{\prime} \mathrm{S}\right.$, $\left.70^{\circ} 02.4^{\prime} \mathrm{E}\right)$, at depths of 2420 to $2450 \mathrm{~m}, 22 \mathrm{~km}$ north of the Rodriguez Triple Junction. The collection site was an active vent field that included black smoker complexes with dense patches of vent-associated animals, including Rimicaris kairei, Bathymodiolus mussel, Alviniconcha snail, Austinograea crab, and Marianactis anemone. Eight individuals of the present new species were captured by the suction sampler loaded on the Shinkai 6500 at the active vent sites. Of these, six specimens were fixed and preserved in $99.5 \%$ ethanol, and the other two were fixed in $2.5 \%$ glutaraldehyde solution and preserved in $70 \%$ ethanol in an on-board laboratory. An additional 15 specimens, sent by Tim Shank to JWM and KZ at the Natural History Museum of Los Angeles County, were collected by the ROV Jason (lowering number 302) in April 2001 from the Edmond Vent Field $\left(23^{\circ} 52.7^{\prime} \mathrm{S}, 6^{\circ} 35.8^{\prime} \mathrm{E}\right)$ at a depth of 3,300 m; several specimens of Rimicaris were also collected during that lowering.

The holotype is deposited in the collections of the National Science Museum, Tokyo (NSMT). The remaining specimens, including paratypes, are housed in JAMSTEC (the Shinkai 6500 specimens) and in the Crustacea collections of the Natural History Museum of Los Angeles County (LACM) (ROV Jason specimens). The specimen size is indicated by the postorbital carapace length (CL).

Two specimens from the Edmond Vent Field, used for SEM observation, were destroyed, and therefore they were not designated as paratypes.

\section{SYSTEMATICS}

\author{
Family ALVINOCARIDIDAE \\ Genus Mirocaris Vereshchaka, 1997 \\ Mirocaris indica sp. nov.
}

(Figs. 1-5)

Chorocaris sp. ? - Hashimoto et al., 2001: 721, Table 1.

Chorocaris n. sp. - Van Dover et al., 2001: 820, Fig. 2E.

Material examined: Central Indian Ridge, Kairei Field, DS “Shinkai 6500”, dive 6K\#665, 25¹9.2'S, 7002.4'E, 2422 m, 24 February 2002. Holotype: female CL 13.0 mm, (NSMT-Cr 16260). Paratypes at JAMSTEC: same site as the holotype, DS "Shinkai 6500", dive 6K\#660: 1 male CL 8.1 mm (No. 47384); 1 female CL $8.3 \mathrm{~mm}$ (No. 47385); same data as the holotype: 1 male CL $5.4 \mathrm{~mm}$ (No. 47292); 1 male CL 6.8 mm (No. 47293); 1 male CL 4.6 mm (No. 47294); 1 female (No. 47295); 1 female CL $10.2 \mathrm{~mm}$ (No. $56320)$.

Paratypes at LACM: Central Indian Ridge, Edmond Vent Field, 23응 $52.7^{\prime} \mathrm{S}, 69^{\circ} 35.8^{\prime} \mathrm{E}, 3,300 \mathrm{~m}$, R/V Knorr cruise KN 162-13, ROV Jason lowering number 302, 25 April 2001: 15 specimens, 2 of which were destroyed for SEM purposes. Remaining (intact) 13 specimens ranging in size from one juvenile (sex indeterminate) of CL $7.3 \mathrm{~mm}$ to large adults of CL $14.3 \mathrm{~mm}$. Individual sizes (CL, in $\mathrm{mm}$ ) of these are as follows: males: 8.2 (with carapace deformed), 9.0, 9.8 (with rostrum tip cracked but attached), 10.2; females: 9.2 , 9.6 (with left part of carapace removed), 10.0, 11.7 (with section of carapace removed), 12.0, 12.6, 13.8, 14.3. These paratypes are housed together as LACM CR 2001-029.1.

Etymology: The specific name, indica, reflects the general geographic environs of this new species, only the second of the Alvinocarididae from the Indian Ocean to be described. 


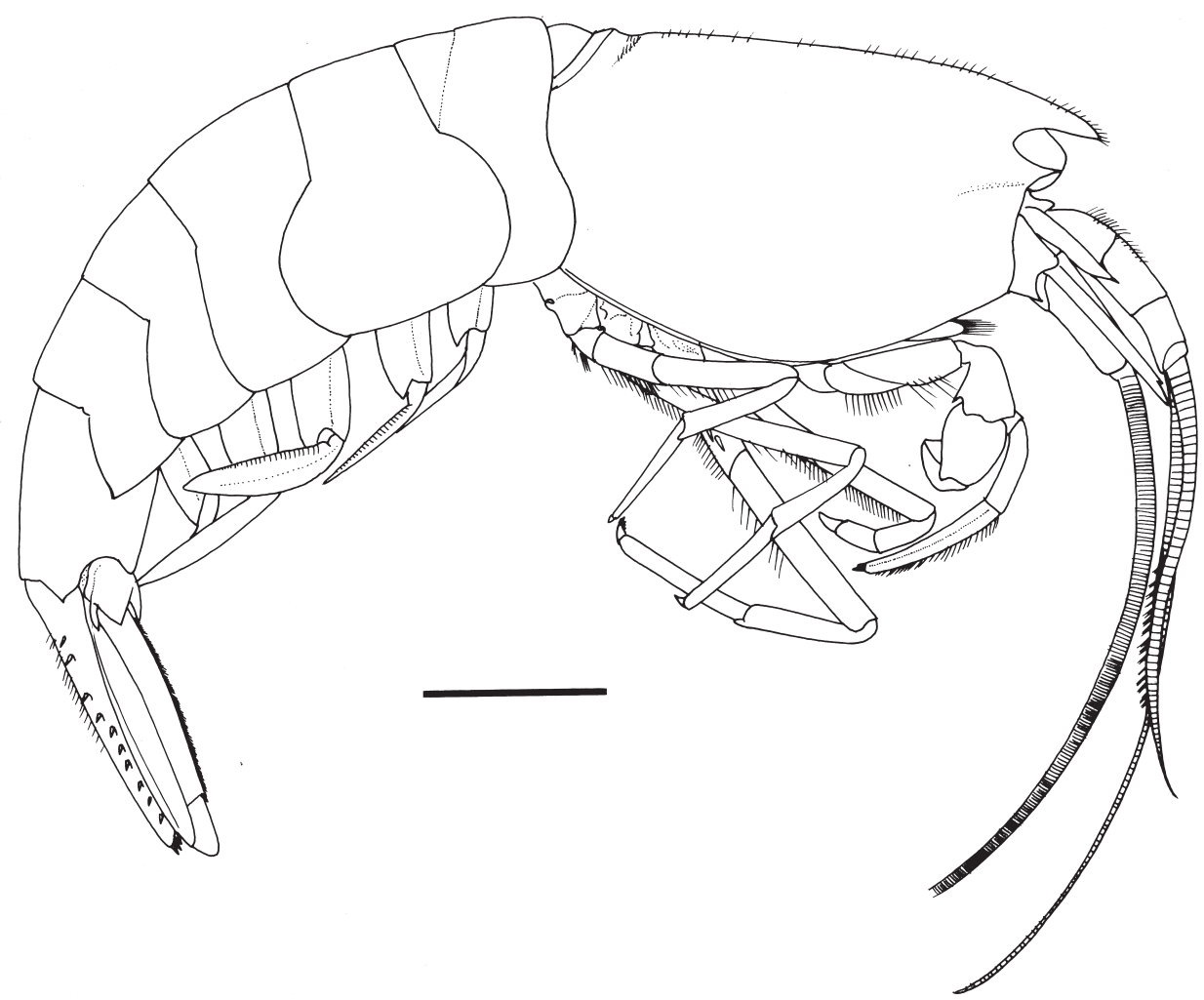

FIG. 1. - Mirocaris indica sp. nov. Habitus, in lateral view. Holotype female (CL $13.0 \mathrm{~mm}$; NSMT-Cr 16260). Scale $=5 \mathrm{~mm}$.

Description: Body (Fig. 1) moderately robust for alvinocaridids. Integument smooth, thin, but not membranous.

Rostrum (Fig. 2A, B) triangular, terminating subacutely or acutely in dorsal view, flattened dorsoventrally, slightly overreaching antennal tooth, directed forward; both dorsal and ventral surfaces not dentate, dorsal surface convex with blunt median ridge. Carapace (Figs. 1,2C) slightly compressed laterally, with sparse short setae along midline (including rostrum), occurring in greater density in anterior part; cuticle surface with short vertical rows of tiny pits visible only under magnification (about $\mathrm{x}$ 30). Orbital margin evenly concave; antennal tooth slightly directed mesially; pterygostomian angle angular, not exceeding antennal tooth, usually with very small tooth. Anterolateral margin between antennal tooth and pterygostomian angle slightly concave, posterior submarginal groove shallow.

Thoracic sternite with pair of slender submedian spines on seventh somite; median spur on eighth somite terminating in acute spine.

Abdomen (Fig. 1) rounded dorsally in all somites; pleura of anterior four somites all broadly rounded; fifth pleuron with small posteroventral tooth. Sixth somite about 1.8 times longer than fifth somite, 1.4 times longer than proximal height; posterolateral process short, terminating in small acute tooth; posteroventral corner produced, terminating in blunt or subacute tooth. First abdominal sternite with pair of small submedian spines, similar spines better developed and more strongly curved mesially on second and third sternites, less developed spines on fourth sternite; fifth sternite with distinct median keel terminating posteriorly in acute spine; sixth sternite flattened, thin, transparent, with small preanal spine.

Telson (Fig. 2F) 1.3-1.4 length of sixth abdominal somite, slightly narrowed posteriorly, width between posterolateral corners about 0.8 of greatest anterior width; distal four-fifths of dorsal surface bearing sinuous row of 10-11 spines on either side (excluding spines at posterolateral corner); posterior margin (Fig. 2G) (in holotype deformed; Fig. 2F) broadly convex, occasionally with shallow median emargination, bearing 12-19 spines in total; 1-3 spines at posterolateral corner simple, lateralmost spine shortest, second lateral spine usually longest; remaining mesial spines bearing marginal setules.

Eye-stalks (Fig. 2A, B) rather large but degenerated, broadly fused mesially without trace of median separation; no faceted structure apparent on 


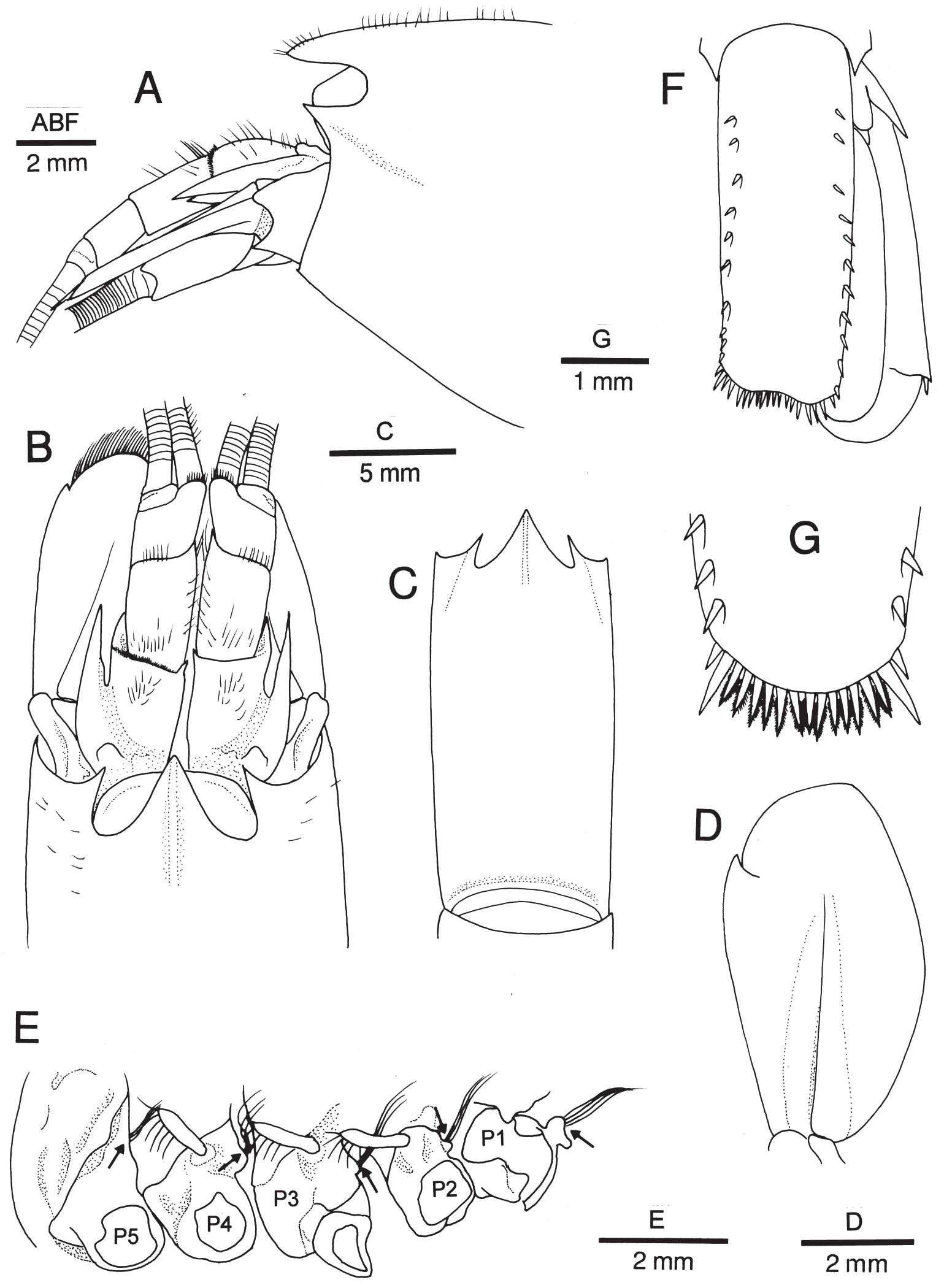

FIG. 2. - Mirocaris indica sp. nov. A, anterior part of carapace and cephalic appendages, lateral view (antennal flagella omitted); B, same, dorsal view; C, carapace, dorsal view; D, left antennal scale, dorsal view; E, right coxae of first to fifth pereopods, ventrolateral view (arrows indicating setobranchs; epipod on first pereopod broken off; setae partially omitted); F, telson and right uropod, dorsal view (setae omitted); G, posterior part of telson, dorsal view. A-F, holotype female (CL 13.0 mm; NSMT-Cr 16260); G, paratype female (CL 10.2 mm; JAMSTEC 56320). Abbreviations: P1-P5 = first to fifth pereopods. 

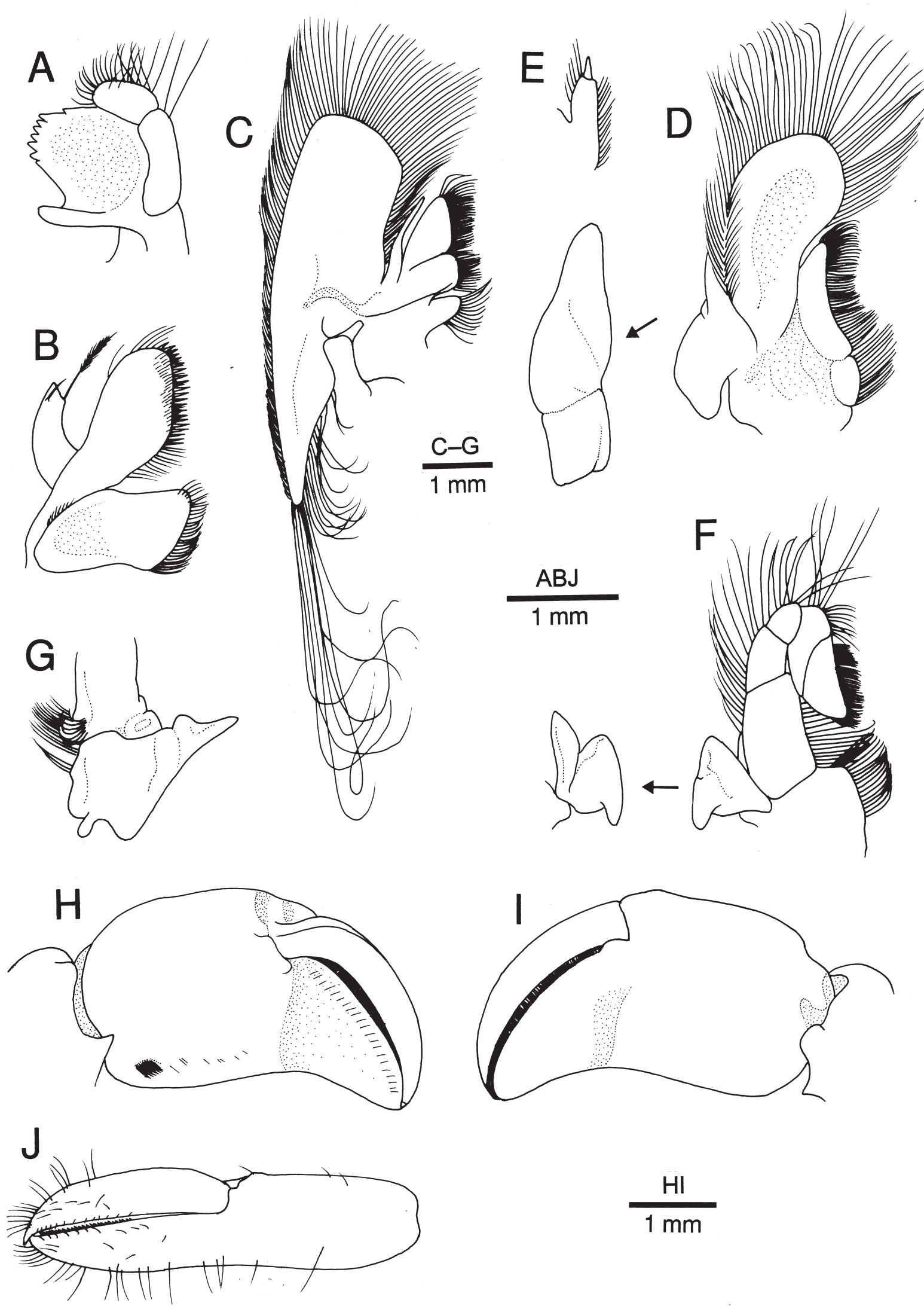

FIG. 3. - Mirocaris indica sp. nov. Mouthparts dissected from right side. A, mandible, dorsal view; B, maxillule, ventral view; C, maxilla, ventral view; D, first maxilliped, ventral view; inset, epipod, dorsal view; E, same, palp, mesial view; F, second maxilliped, ventral view; inset, epipod and podobranch, dorsal view; G, coxa and proximal part of antepenultimate segment of third maxilliped, dorsal view; $\mathrm{H}$, chela of first pereopod, inner view; I, same, outer view; J, chela of second pereopod, outer view. Holotype female (CL 13.0 mm; NSMT-Cr 16260). 
corneal region; anterior surface of eye unarmed.

Antennular peduncles (Fig. 2A, B) stout, slightly flattened dorsoventrally. First segment with distal width nearly half its length; dorsal surface convex in distal part, but remaining proximal part concave below, continuous with deep groove separating basal segment and stylocerite; distal margin slightly oblique in dorsal view; distolateral tooth strong, reaching nearly to midlength of second segment, overlapped by stylocerite, distomesial tooth much smaller than distolateral tooth; ventromesial ridge with 1 spinule arising at about midlength of segment; stylocerite strong, tapering to slender point reaching or overreaching midlength of second peduncular segment. Second segment with scattered short setae on dorsal surface; distomesial tooth larger than corresponding tooth on first segment. Third segment almost as wide as it is long. Flagella (Fig. 1) rather stout, unequal, inserted side by side on oblique terminal margin of third segment; lateral flagellum shorter than mesial, proximal aesthetascbearing portion occupying about 0.8 of total length of flagellum; each article with tuft of sensory setae; mesial flagellum with annuli much denser than those on lateral flagellum.

Antenna (Fig. 2A, B) with basicerite stout, bearing blunt dorsolateral distal projection and acute ventrolateral distal tooth exceeding former projection. Carpocerite (fifth segment of antennal peduncle) stout, cylindrical, exceeding midlength of scaphocerite. Antennal scale (Fig. 2D) broadly oval with greatest width across level of midlength, 1.8 times longer than wide; lateral margin slightly convex, terminating in short, stout tooth separated by narrow incision and considerably exceeded by strongly produced, rounded blade; dorsal surface with distinct median ridge somewhat diverging against lateral margin. Flagellum stouter than antennular flagella, slightly longer than body, annuli dense.

Mandible (Fig. 3A) with incisor process broad, tapering distally, bearing 8 unequal acute or subacute teeth on mesial margin (distalmost tooth distinctly separated from remaining teeth); molar process slender, unarmed, extending as far as incisor process; basal article of palp with broad notch on mesial surface, distal article stout, shorter than basal article, bearing numerous plumose setae of differing lengths. Maxillule (Fig. 3B) with coxal endite slightly tapering distomesially, with dense setae on mesial margin; basial endite broad, mesial margin with 2 rows of small spines (spines more numerous and denser in dorsal row than in ventral row); ventral surface of basial endite with submarginal row of short setae; palp somewhat curved, slightly bilobed distally, bearing 2 setae; outer seta short, simple, arising subterminally from ventral surface slightly proximal to base of somewhat produced outer lobule; inner lobule small, bearing a long plumose seta distally.

Maxilla (Fig. 3C) with coxal endite composed of 2 strongly unequal lobes, distal lobe considerably reduced and showing as slender projection arising from base of proximal lobe, bearing 1 apical seta. Basial endite divided in 2 unequal lobes bearing dense marginal setae, proximal lobe subrectangular, distal lobe subtriangular; palp slender, sinuously curved, reaching distal lobe of basial endite; scaphognathite broad, without facial setae; anterior lobe of scaphognathite subovate with densely setose margin bearing longest setae along distomesial sector, posterior lobe elongate subtriangular, fringed on mesial to terminal margins with very long setae becoming longer posteriorly.

First maxilliped (Fig. 3D) with coxal endite somewhat thickened, with thick setae on mesial face; basial endite moderately broad, with dense cluster of setae on slightly concave mesial margin; palp (Fig. 3E; not visible in ventral view) stout, composed of 2 articles (distal article very small), weakly curved mesially; exopod greatly expanded, fringed with double row of long plumose setae, lacking flagellum, ventral surface concave, devoid of facial setae; epipod large, foliaceous, faintly bilobed.

Second maxilliped (Fig. 3F) somewhat pediform, composed of 6 segments. Coxa slightly expanded mesially, with numerous setae on mesial face. Basis and ischium completely fused, this fused segment longest, with row of dorsally curved setae on mesial margin forming basket-like structure. Merus about half length of basis-ischium fused segment, with long plumose setae on lateral face. Carpus short, with long plumose setae on outer surface. Propodus with row of setae on margin; articulation between propodus and dactylus strongly oblique. Dactylus longer than propodus, tapering to rounded apex, bearing dense cluster of short setae on mesial to distal margins. Exopod absent; epipod (Fig. 3F, inset) subtriangular, with stout rudiment of podobranch reaching midlength of basis-ischium fused segment.

Third maxilliped (Fig. 4A) composed of 4 clearly separated segments, slightly overreaching anterior margin of scaphocerite. Coxa (Fig. 3G) stout; epipod 

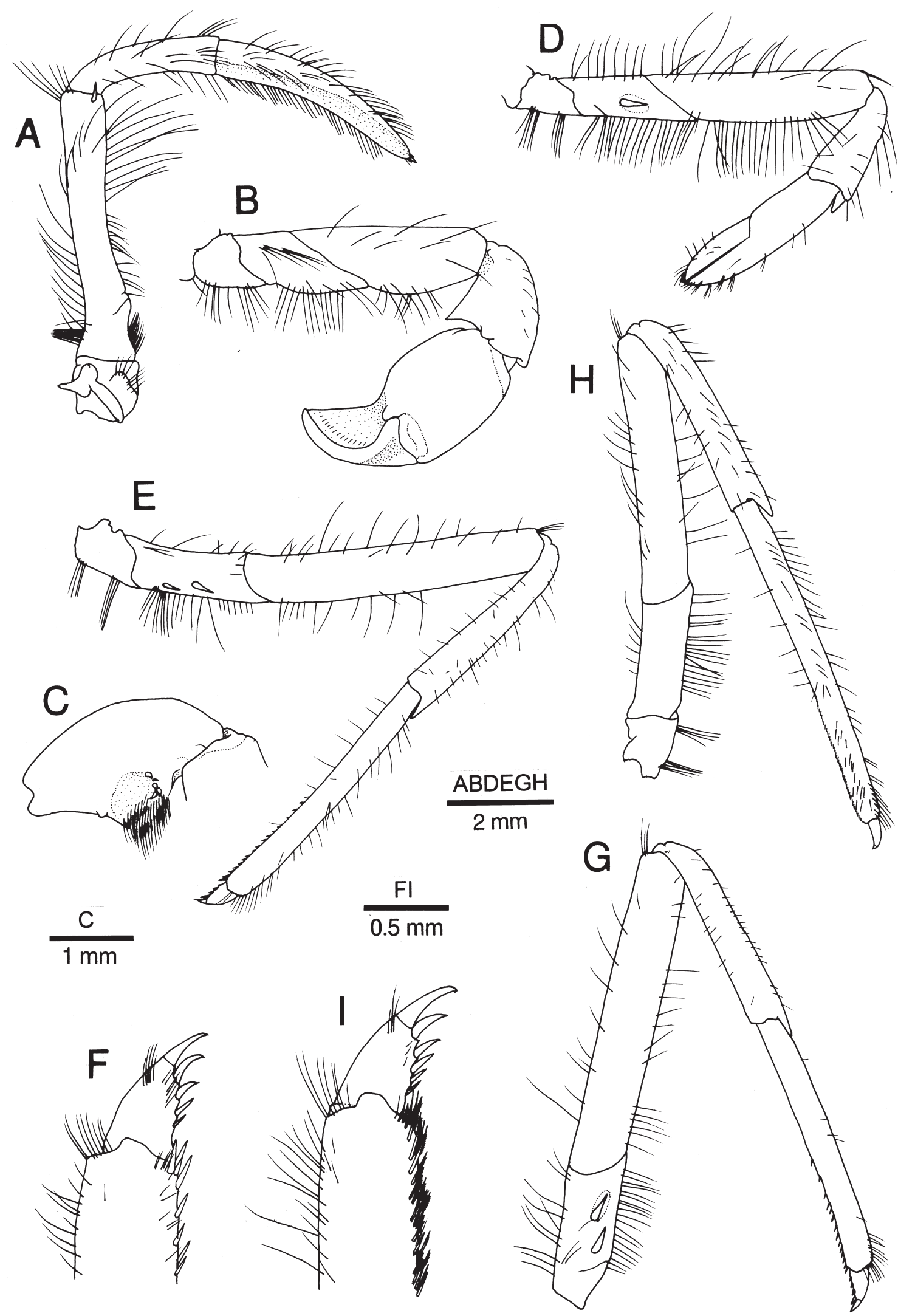

FIG. 4. - Mirocaris indica sp. nov. Right thoracic appendages. A, third maxilliped, lateral view; B, first pereopod, lateral view; C, carpus of first pereopod, mesial view; D, second pereopod, lateral view; E, third pereopod, lateral view; $F$, same, dactylus and distal part of propodus, lateral view; G, fourth pereopod, lateral view; H, fifth pereopod, lateral view; I, same, dactylus and distal part of propodus, lateral view. Holotype female (CL $13.0 \mathrm{~mm}$; NSMT-Cr 16260). 
composed of laterally produced process and strap-like part with terminal hook corresponding to setobranch on first pereopod. Antepenultimate segment (basisischium-merus fused segment, but fusion between basis and ischium incomplete with suture on ventral surface) somewhat flattened dorsoventrally, strongly sinuously curved in dorsal view, setose, with slender spine at distolateral ventral corner; cluster of short to long setae at proximomesial portion (Fig. 3G). Penultimate segment (= carpus) weakly curved ventrally, with dense setae on mesial surface. Ultimate segment slightly curved, gradually tapering distally, mesial section with obliquely transverse tracts of short, stiff setae, long setae scattered along lateral edge, and 2 or 3 terminal spines.

First pereopod (Fig. 4B) stout, slightly overreaching (when extended) distal margin of scaphocerite at most, with chela and carpus oriented toward midline. Ischium and merus with scattered plumose setae on lateral and ventral surfaces. Merus somewhat compressed laterally and slightly tapering distally, ventral surface slightly concave for reception of flexed carpus. Carpus shorter than merus, somewhat inflated, irregularly funnel-shaped, dorsal surface bent at right angle near tapered proximal end articulating with merus; distolateral margin slightly produced medially; distomesial margin more strongly produced, forming broadly triangular lobe; mesial face (Figs. 4C, 5A, C) concave, with large patch of setae composing grooming apparatus and 2-5 small spines on proximal border of setal patch. Palm (Fig. $3 \mathrm{H}$, I) short, strongly inflated, with patch of short setae on mesial surface ventrally (Fig. 5C). Fingers curved and closing without gap; internal surfaces deeply concave; external surface of both fingers convex; cutting edges uniformly offset, each armed with row of uniform, minute, erect, closely set teeth (Fig. 5B, D); cutting edge of fixed finger bordered with narrow, thin chitinous plate including tip; internal surface with submarginal row of widely spaced short setae along cutting edge; external surface of fixed finger with some submarginal rows of longer setae (Fig. 5B). Dactylus subequal to palm in length, uniformly narrowed distally, considerably flattened in distal half; internal surface also with submarginal row of short, sparse setae along cutting edge; external surface lacking conspicuous rows of longer setae along cutting edge.

Second pereopod (Fig. 4D) slightly thinner than other pereopods, reaching distal margin of scaphocerite at most. Articulation between ischium and merus oblique. Ischium with 1 movable spine strongly pressed on lateral surface and row of setae on dorsal and ventral margins. Merus about 4.4 times longer than maximum height, with row of setae on dorsal and ventral margins. Carpus with sparse setae on dorsal and lateral surfaces. Chela (Fig. 3J) about 1.7 times length of carpus, about 4.0 times longer than wide; fingers slightly longer than palm, each terminating in small corneous claw (Fig. 3D), crossing at tip; external surfaces slightly depressed toward cutting edges, with scattered very short setae and longer setae on distal part of fingers; cutting edges each with row of minute corneous spinules.

Third to fifth pereopods generally similar in structure, but increasing in length from anterior pair to posterior pair (Fig. 4E, G, H). Third pereopod (Fig. 4E) overreaching distal margin of antennal scale by length of dactylus and half length of propodus; ischium with 2 spines on lateral surface ventrally; merus about 5.8 times longer than high, with sparse setae; carpus-propodus combined slightly shorter than merus-ischium combined; carpus 0.6-0.7 times as long as propodus; propodus (Fig. $4 \mathrm{~F}$ ) with 2 rows of spinules on ventral surface (spinules of mesial row fewer than those of lateral row); dactylus (Fig. 4F) stout, 0.2-0.4 times as long as propodus (including unguis), ventral margin with 3-4 accessory spinules becoming larger distally, unguis clearly demarcated, elongate. Fourth pereopod (Fig. 4G) overreaching antennal scale by length of dactylus; ischium with 0-1 spine; carpus-propodus combined subequal in length to merus-ischium combined. Fifth pereopod (Fig. 4H) reaching distal margin of scaphocerite by length of dactylus; ischium unarmed; carpus-propodus combined longer than merus-ischium combined; ventral surface of propodus (Fig. 4I) with double or triple row of setulose spinules on lateral side and single row of simple spinules on mesial side.

Pleurobranchs on fourth to eighth thoracic somites asymmetrically Y-branched, noticeably increasing in length posteriorly, apices directed forward. Arthrobranchs on third to seventh thoracic somites moderately developed, nearly symmetrically U-branched; last arthrobranch on seventh somite distinctly smaller than those preceding. Epipods on first to fourth pereopods strap-like, similar shape to that on third maxilliped (broken on first pereopod of holotype and therefore not shown in Fig. 2E). Setobranchs on first to fifth pereopods corresponding to epipods on third maxilliped to fourth pereopod respectively (Fig. 2E). 


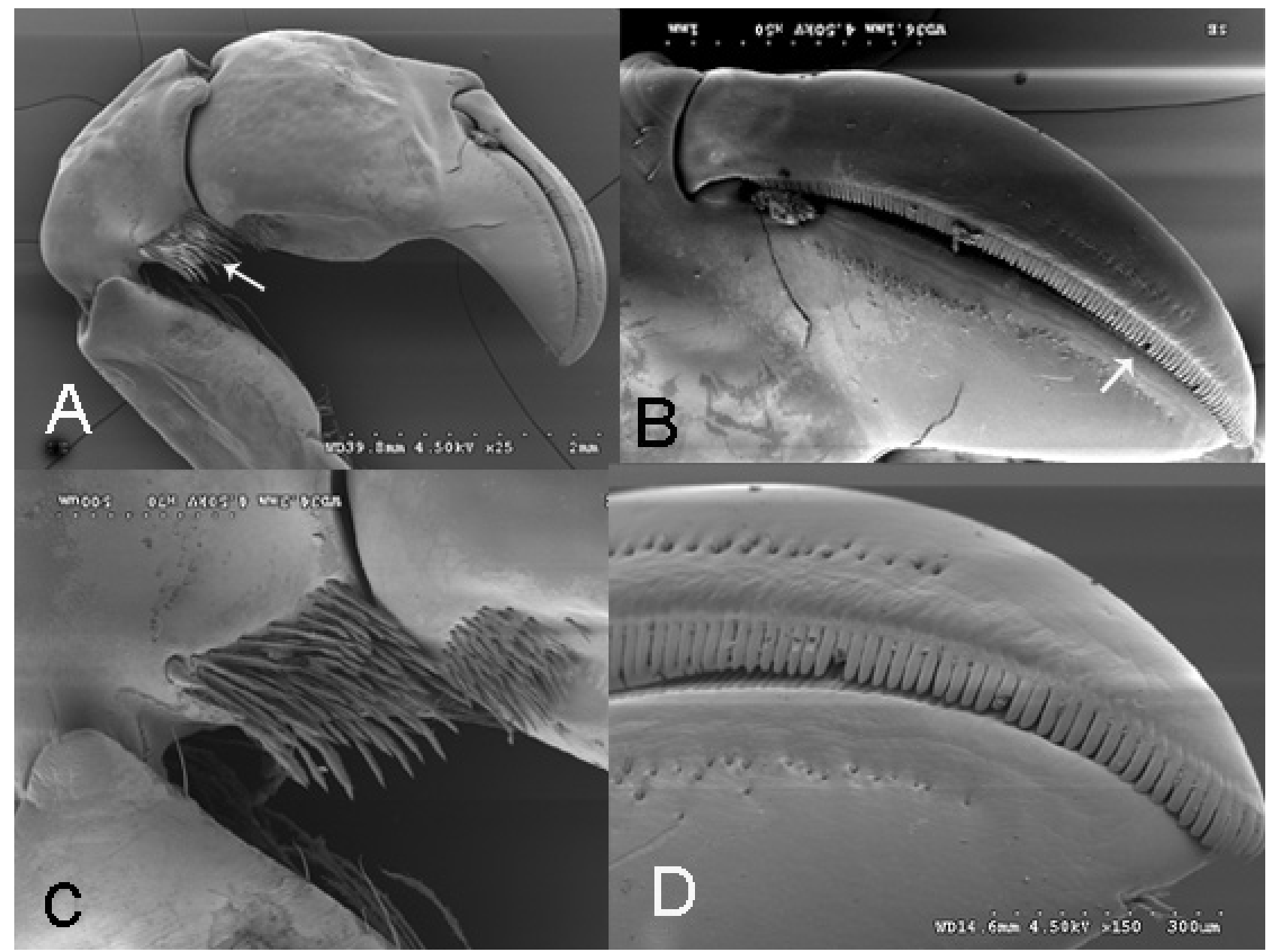

FIG. 5. - Mirocaris indica sp. nov. SEM figures. A, chela and carpus of left first pereopod, lateral view; B, external surface of chela of left first pereopod; C, higher magnification of serrate setae on ventromesial face of carpus (carpal cleaning brush) and similar setae of propodus (white arrow in A); D, higher magnification of teeth on cutting edge of dactylus (approximate area of white arrow in B). Non-type (CL $11.0 \mathrm{~mm}$; LACM, not catalogued).

Endopod of female first pleopod uniformly tapering with margins fringed sparsely with plumose setae; second and third pleopods lacking appendix interna while fourth pleopods with slender, simple appendix interna, fifth pleopods with well-developed appendix interna bearing cluster of cincinnuri.

Uropod (Fig. 2F) with both rami elongate oval, exceeding posterior margin of telson. Endopod shorter and narrower than exopod. Exopod with straight lateral margin terminating in tiny acuminate tooth; long movable spine arising just mesial to distolateral tooth; suture distinct, sinuous.

Color: In life, body and appendages are generally white, but dorsal surface of carapace and anterior two abdominal somites reddish; eyes yellowish.

Preserved specimens uniformly beige or tan to light grey.
Variation: The telson of the holotype is abnormally deformed (Fig. 1F). The normal condition is represented by the paratypes (Fig. 1G).

Comparison: Morphologically, Mirocaris indica closely resembles $M$. fortunata, the sole known representative of the genus and a species known only from vent fields of the Mid-Atlantic Ridge. It is generally known that congeneric species of alvinocaridid shrimp share many morphological traits, despite the great distance separating the species (e.g. see Williams, 1988; Kikuchi and Ohta, 1995; Webber, 2004; Komai and Segonzac, in press). The constant morphological difference between Mirocaris indica and $M$. fortunata is seen in the setation of the fingers of the first chela. The new species lacks submarginal rows of short to long setae on the external surfaces of the fingers of the first chela, which are present in M. fortunata. Within the Alvinocarididae, 
other than in M. fortunata, the presence of the setal rows is known only in Nautilocaris saintlaurentae Komai and Segonzac, 2004 from the south-western Pacific vent fields (Komai and Segonzac, 2004). In addition, the new species may attain a larger size at maturity than $M$. fortunata; the largest known specimen of M. fortunata is CL $10.5 \mathrm{~mm}$ (Vereshchaka, 1997; as M. keldyshi), whereas the largest specimen of $M$. indica is CL $14.3 \mathrm{~mm}$.

\section{DISCUSSION}

Hashimoto et al. (2001) and Van Dover et al. (2001) reported two shrimp species from the vent fields on the Central Indian Ridge, Rimicaris aff. exoculata and Chorocaris n. sp. Watabe and Hashimoto (2002) later described the Rimicaris species as new, $R$. kairei, in spite of the low genetic divergence suggested by Van Dover et al. (2001). In the process of sorting our specimens, we did not encounter species assignable to Chorocaris, but we did find species that could be assigned to Mirocaris (based on characters given by Komai and Segonzac, 2003). Both the species of Rimicaris described by Watabe and Hashimoto (2001) and the new Mirocaris described herein were collected on the same lowering of the ROV Jason (lowering 302). Considering the superficial resemblance between Chorocaris and Mirocaris, there is little doubt that the Chorocaris n. sp. reported by Hashimoto et al. (2001) and Van Dover et al. (2001) actually represents Mirocaris indica.

Van Dover et al. (2001) noted affinities between Indian Ocean and western Pacific taxa, such as Bathymodiolus mussels, polynoid scale worms, Austinograea crabs and hairy gastropods of the genus Alviniconcha. However, it is remarkable that the shrimp fauna of the Central Indian Ridge is rather similar to that of the Mid-Atlantic Ridge. Neither Mirocaris nor Rimicaris has been found in the Pacific Ocean. Thus, it has been suggested that the vent fauna of the Indian Ridge is composed of multiple taxa originating from both the Atlantic and Pacific Oceans (Hashimoto et al., 2001). The alternative explanation - that the fauna originated in the Indian Ocean and subsequently spread to the Atlantic and Pacific - would demand an explanation for how the shrimp fauna moved westward, whereas the crab fauna moved to the east (i.e. into the Indo-West Pacific).
Our report extends the known range of the genus Mirocaris to the Indian Ocean, as the other representative of the genus, $M$. fortunata, is thus far restricted to the Mid-Atlantic Ridge between $38^{\circ} \mathrm{N}$ and $14^{\circ} \mathrm{N}$ (Komai and Segonzac, 2003). It is remarkable that the distribution pattern of species in Mirocaris and Rimicaris is nearly identical despite the different evolutionary history suggested by Shank et al. (1999). Shank et al. (1999) estimated that Mirocaris fortunata shared a last common ancestor with other alvinocaridid species some 6.7 to 11.7 MYA, while $R$. exoculata and $C$. chacei shared a last common ancestor 0.42 to 0.5 MYA. The close morphological similarity between the two known species of Rimicaris also supports the theory that Rimicaris is a relatively young genus. Preliminary molecular data provided by Van Dover et al. (2001) may indicate that R. kairei is conspecific with $R$. exoculata, in spite of some morphological differences (Watabe and Hashimoto, 2002). According to the hypothesis of Shank et al. (1999), Mirocaris is a relatively old genus, although the speciation between $M$. fortunata and $M$. indica may be a more recent event.

Morphology of the mouthparts and thoracic appendages suggests that Mirocaris indica is not a "bacteria farmer" but instead feeds mainly on substrate fauna. The setal rows that serve to distinguish the two species probably enable $M$. fortunata to pick up particles from substrates for efficient feeding. Indeed, we have encountered many specimens of $M$. fortunata bearing substrate-derived particles attached to the setal rows on the first chelae (personal observation). Therefore, given the vital function of the setal rows, the morphological difference between $M$. indica and $M$. fortunata is possibly highly significant.

In addition to the specimens of Mirocaris indica and Rimicaris kairei collected by the ROV Jason (lowering 302, April, 2001), other shrimp from the Central Indian Ridge were collected on ROV Jason lowerings 297 (two specimens) and 296 (four specimens). These specimens, currently with JWM at the Natural History Museum of Los Angeles County, may represent still more undescribed alvinocaridid shrimp species from the Indian Ocean.

\section{ACKNOWLEDGEMENTS}

JWM and KZ sincerely thank Timothy M. Shank, Woods Hole Oceanographic Institution, for 
sending specimens from the ROV Jason lowering 302 to the Natural History Museum of Los Angeles County to be examined. ST and JH thank the manager, Mr. Yoshiji Imai, the operation team of the Shinkai 6500, the captain Mr. Sadao Ishida, and the crews of the $R / V$ Yokosuka for their helpful support in collecting specimens. TK very much appreciates Michél Segonzac of Ifremer, France, for making specimens of $M$. fortunata available for study, and for discussing various aspects of biology of vent endemic shrimps. This study was supported in part by U.S. National Science Foundation grants DEB 9978193 (from the PEET initiative of the Systematic Biology program) and DBI 0138674 (a Biological Research Collections grant supporting the Marine Biodiversity Processing Center at the Natural History Museum of Los Angeles County).

\section{REFERENCES}

Baba, K. and A.B. Williams. - 1998. New Galatheoidea (Crustacea, Decapoda, Anomura) from hydrothermal systems in the West Pacific Ocean: Bismarck Archipelago and Okinawa Trough. Zoosystema, 20: 143-156.

Guinot, D. and L.A. Hurtado. - 2003. Two new species of hydrothermal vent crabs of the genus Bythograea from the southern East Pacific Rise and from the Galapagos Rift (Crustacea Decapoda Brachyura Bythograeidae). C. R. Biol., 326: 423-439.

Guinot, D., L.A. Hurtado and R. Vrijenhoek. - 2002. New genus and species of brachyuran crab from the southern East Pacific Rise (Crustacea Decapoda Brachyura Bythograeidae). C. $R$. Biol., 325: 1143-1152.

Hashimoto, J., S. Ohta, T. Gamo, H, Chiba, T. Yamaguchi, S. Tsuchida, T. Okudaira, H. Watabe, T. Yamanaka and M. Kitazawa. 2001. - First hydrothermal vent communities from the Indiana Ocean discovered. Zool. Sci., 18: 717-721.

Hayashi, K. and J. Ohtomi. 2001. - A new species of the genus Periclimenes (Decapoda: Caridea: Palaemonidae) collected from hydrothermal vent fields in Kagoshima Bay, Japan. Crust. Res., 30: 160-171.

Kikuchi, T. and J. Hashimoto. - 2000. Two new caridean shrimps of the family Alvinocarididae (Crustacea: Decapoda) from a hydrothermal vent field at the Minami-Ensei Knoll in the MidOkinawa Trough, Japan. Species Diversity, 5: 135-148.

Kikuchi, T. and S. Ohta. - 1995. Two caridean shrimps of the families Bresiliidae and Hippolytidae from a hydrothermal field on the Iheya Ridge, off the Ryukyu Islands, Japan. J. Crust. Biol., 15: 771-785.

Komai, T. and M. Segonzac. - 2003. A review of the hydrothermal vent shrimp genus Mirocaris, redescription of $M$. fortunata (Martin and Christiansen), and reassessment of the taxonomic status of the family Alvinocarididae (Crustacea: Decapoda: Caridea). Cah. Biol. Mar., 44: 199-215.

Komai, T. and M. Segonzac. - 2004. A new genus and species of alvinocaridid shrimp (Crustacea: Decapoda: Caridea) from the
North Fiji and Lau Basins, southwestern Pacific. J. Mar. Biol. Assoc. U.K., 84: 1179-1181.

Komai, T. and M. Segonzac. - 2005a. A revision of the genus Alvinocaris Williams and Chace (Crustacea: Decapoda: Caridea: Alvinocarididae), with descriptions of a new genus and a new species of Alvinocaris. J. Nat. Hist., 39: 1111-1175.

Komai, T. and M. Segonzac. - 2005b. Two new species of Nematocarcinus A. Milne-Edwards, 1881 (Crustacea: Decapoda: Caridea: Nematocarcinidae) from hydrothermal vents on the North and South East Pacific Rise. Zoosystema, 27: 243-364.

Komai, T., T.M. Shank and C.L. Van Dover. - In press. A new species of Alvinocaris (Crustacea: Decapoda: Caridea: Alvinocarididae) and new record of A. muricola from methane seeps on the Blake Ridge Diapir, Northwestern Atlantic. Zootaxa.

Martin, J.W. and J.C. Christiansen. - 1995. A new species of the shrimp genus Chorocaris Martin and Hessler, 1990 (Crustacea, Decapoda, Bresiliidae) from hydrothermal vent fields along the Mid-Atlantic Ridge. Proc. Biol. Soc. Wash., 108: 220-227.

Martin, J.W. and T.A. Haney. - In press. Decapod crustaceans from hydrothermal vents and cold seeps: a review through 2004. Zool. J. Lin. Soc. London.

Martin, J.W. and T.M. Shank. - 2005. A new species of the shrimp genus Chorocaris (Decapoda: Caridea: Alvinocarididae) from hydrothermal vents in the eastern Pacific Ocean. Proc. Biol. Soc. Wash., 118: 183-198.

Shank, T.M. and J.W. Martin. - 2003. A new caridean shrimp of the family Alvinocarididae from thermal vents at Menez Gwen on the Mid-Atlantic Ridge. Proc. Biol. Soc. Wash., 116: 158-167.

Shank, T.M., M.B. Black, K.M. Halanych, R.A. Lutz and R.C. Vrijenhoek. - 1999. Miocene radiation of deep-sea hydrothermal vent shrimp (Caridea: Bresiliidae): Evidence from mitochondrial cytochrome oxidase subunit I. Mol. Phyl. Evol., 13: 244-254.

Takeda, M., J. Hashimoto and S. Ohta. - 2000. A new species of the family Bythograeidae (Crustacea, Decapoda, Brachyura) from the hydrothermal vents along volcanic front of the Philippine Sea Plates. Bull. Natn. Sci. Mus., Tokyo, Ser. A, 26: 159-172.

Tsuchida, S. and J. Hashimoto. - 2002. A new species of bythograeid crab, Austinograea rodriguezensis (Decapoda: Brachyura), associated with active hydrothermal vents from the Indian Ocean. J. Crust. Biol., 22: 642-650.

Van Dover, C. L., S.E. Humphris, D. Fornari, C.M. Cavanaugh, R. Collier, S.K. Goffredi, J. Hashimoto, M.D. Lilley, A.L. Reysenbach, T.M. Shank, K.L. Von Damm, A. Banta, R.M. Gallant, D. Gotz, D. Green, J. Hall, T.L. Harmer, L.A. Hurtado, P. Johnson, Z.P. McKiness, C. Meredith, E. Olson, I.L. Pan, M. Turnipseed and Y. Won. - 2001. Biogeography and ecological setting of Indian Ocean hydrothermal vents. Science, 294: $818-823$.

Vereshchaka, A.L. - 1997. A new family for a deep-sea caridean shrimp from North Atlantic hydrothermal vents. J. Mar. Biol. Ass. U. K., 77: 425-438.

Watabe, H. and J. Hashimoto. - 2002. A new species of the genus Rimicaris (Alvinocarididae: Caridea: Decapoda) from the active hydrothermal vent field, "Kairei Field," on the Central Indian Ridge, the Indian Ocean. Zool. Sci., 19: 1167-1174.

Webber, W.R. - 2004. A new species of Alvinocaris (Crustacea: Decapoda: Alvinocarididae) and new records of alvinocaridids from hydrothermal vents north of New Zealand. Zootaxa, 444: $1-26$.

Williams, A.B. - 1988. New marine decapod crustaceans from waters influenced by hydrothermal, discharge, brine and hydrocarbon seepage. Fish. Bull., 86: 263-287.

Scient. ed.: E. Macpherson 
